Article

\title{
Catalytic oxidation of styrene to benzaldehyde over a copper Schiff-base/SBA-15 catalyst
}

\author{
Xuecheng Zhu, Ruwei Shen, Lixiong Zhang* \\ State Key Laboratory of Materials-Oriented Chemical Engineering, College of Chemistry and Chemical Engineering, Nanjing Tech University, Nanjing \\ 210009, Jiangsu, China
}

A R T I C L E I N F O

Article history:

Received 1 March 2014

Accepted 28 April 2014

Published 20 October 2014

Keywords:

Copper(II) Schiff base

SBA-15

Styrene oxidation

Benzaldehyde

Heterogeneous catalysis

\begin{abstract}
A B S T R A C T
The amino-modified mesoporous material SBA-15 $\left(\mathrm{NH}_{2}\right.$-SBA-15) was prepared via co-condensation of tetraethylorthosilicate with 3-aminopropyltriethoxysilane in the presence of an amphiphilic triblock copolymer as a pore-directing agent under acidic conditions. The SBA-15-supported $\mathrm{Cu}$ Schiff-base complex (Cu-SBA-15) was then synthesized by condensation of salicylaldehyde with $\mathrm{NH}_{2}$-SBA-15, followed by the addition of a solution of $\mathrm{Cu}\left(\mathrm{NO}_{3}\right)_{2}$. The supported complex was systematically characterized by elemental analysis, inductive coupled high frequency plasma atomic emission spectrometry, powder X-ray diffraction, Fourier transform infrared spectroscopy, ultraviolet-visible spectroscopy, field scanning electron microscopy, transmission electron microscopy, $\mathrm{N}_{2}$ absorption-desorption, and thermo gravimetric analysis, and was used as the catalyst for the selective oxidation of styrene to benzaldehyde. The influence of the reaction parameters was assessed. The maximum conversion of styrene was $84.4 \%$ and the selectivity for benzaldehyde was $83.9 \%$, when the reaction was conducted with a $2: 1$ molar ratio of $\mathrm{H}_{2} \mathrm{O}_{2}$ :styrene in the presence of $3.8 \mathrm{wt} \%$ catalyst at $100{ }^{\circ} \mathrm{C}$ for $8 \mathrm{~h}$. The TOF was $261.1 \mathrm{~h}^{-1}$, and the catalyst could be used three times without significant loss of activity. The uniformly sized pore channels, high specific surface area, and well-distributed active centers of the catalyst may contribute to the high activity.
\end{abstract}

(C) 2014, Dalian Institute of Chemical Physics, Chinese Academy of Sciences. Published by Elsevier B.V. All rights reserved.

\section{Introduction}

Benzaldehyde is an important and valuable fine chemical that has been widely used in the synthesis of several substances, including perfumes, dyes, and pharmaceuticals [1]. Generally speaking, it can be obtained via several routes including benzyl alcohol oxidation, indirect electrochemical oxidation of toluene, benzoic acid hydrogenation, and benzyl chloride hydrolysis [2]. However, these methods suffer from lengthy procedures, expensive starting materials, and the generation of copious and toxic waste, which is environmentally undesirable. The most ideal preparation method is the direct oxidation of toluene with air or oxygen as the oxidant in the presence of a catalyst. Nevertheless, the lack of an efficient catalyst has curtailed the adoption of this method [3].

Recently, the synthesis of benzaldehyde by styrene oxidation has drawn much attention as the process is simple and environmentally friendly [4,5]. The key to the successful use of this transformation is the design of an active, selective, and recyclable catalyst. Various catalysts, such as metal oxides [6-10], metals [11,12], metal doped zeolites [13,14], solid acids $[15,16]$, and metal Schiff bases or salen complexes $[17,18]$, have been discussed. Among these, the metal Schiff-base complexes demonstrate high catalytic reactivity. However, these homogenous catalysts are usually difficult to separate from the reaction mixture, making the entire catalytic process unattractive for

\footnotetext{
* Corresponding author. Tel: +86-25-83172265; Fax: +86-25-83172263; E-mail: lixzhang@njtech.edu.cn 
industrial application. Consequently, much attention has been focused on immobilizing the complexes on solid supports such as zeolites [19-22], ordered mesoporous silicates [23-28] or polymers [29-31] to afford heterogeneous catalysts. For example, Islam et al. [29] reported a reusable polymer-anchored $\mathrm{Cu}$ (II) complex for the oxidation of styrene to benzaldehyde with TBHP as oxidant. However, the conversion of styrene and the selectivity for benzaldehyde were only $53 \%$ and $52 \%$, respectively. Yang et al. [24] prepared a series of SBA-15-supported Cu(II) and V(IV) Schiff-base complexes to study the oxidation of styrene. They found that the supported oxovanadium catalyst showed good selectivity for benzaldehyde using $\mathrm{H}_{2} \mathrm{O}_{2}$ as the oxidant. The conversion of styrene reached $84.1 \%$ and the selectivity for benzaldehyde was up to $83.3 \%$. However, an organic solvent was used. In addition, a post-synthesis grafting method was employed for the surface modification. In summary, although the modified solid support generally maintained the ordered structure of the parent materials, the distribution of amino groups varied, largely depending on the reactivity and concentration of the precursors used as well as the reaction conditions. The result was inferior catalytic activity and recoverability [32-35].

In this paper, we report the direct synthesis of a uniform amino-modified SBA-15 ( $\left.\mathrm{NH}_{2}-\mathrm{SBA}-15\right)$ based on a single-step co-condensation of tetraethylorthosilicate (TEOS) with 3-aminopropyltriethoxysilane (APTES). The condensation reaction took place in the presence of an amphiphilic PEO-PPO-PEO triblock copolymer (P123) as a pore-directing agent. Treatment of the prepared $\mathrm{NH}_{2}$-SBA-15 with salicylaldehyde under condensation conditions followed by the addition of a solution of $\mathrm{Cu}\left(\mathrm{NO}_{3}\right)_{2}$ formed the SBA-15-supported $\mathrm{Cu}(\mathrm{II})$ Schiff-base complex (Cu-SBA-15). The immobilized complex was successfully used as a catalyst for the selective oxidation of styrene to benzaldehyde in an aqueous medium.

\section{Experimental}

\subsection{Catalyst preparation}

\subsubsection{Preparation of $\mathrm{NH}_{2}-\mathrm{SBA}-15$}

$\mathrm{NH}_{2}$-SBA-15 was prepared via the co-condensation method described in the literature [36]. P123 (4.0 g, Sigma-Aldrich) was dissolved in $125.0 \mathrm{~g}$ aqueous $\mathrm{HCl}$ ( $2 \mathrm{~mol} / \mathrm{L}$ ). After vigorous stirring at $40{ }^{\circ} \mathrm{C}$ for $4 \mathrm{~h}, 7.9 \mathrm{~mL}$ TEOS was added dropwise. The resultant solution was pre-hydrolyzed for $1 \mathrm{~h}$ before $0.92 \mathrm{~mL}$ APTES (Yaohua Chemical Industry, Shanghai, China) was added. After stirring for $20 \mathrm{~h}$, the white solution was transferred into a polypropylene bottle, and aged at $90{ }^{\circ} \mathrm{C}$ for $24 \mathrm{~h}$. The solid was collected by suction filtration and dried at $50{ }^{\circ} \mathrm{C}$ overnight. The residual P123 was removed by extraction with boiled ethanol (1.0 g of as-synthesized material per $200 \mathrm{~mL}$ of ethanol and $10 \mathrm{~mL}$ of concentrated $\mathrm{HCl}$ ) for $24 \mathrm{~h}$. The solid was collected by suction filtration, washed with water and ethanol, and dried at $50{ }^{\circ} \mathrm{C}$ overnight. Elemental analysis gave $\mathrm{C} 8.00 \%$, H 3.27\%, N 1.53\%. The calculated N content was $1.09 \mathrm{mmol} / \mathrm{g}$.
$\mathrm{NH}_{2}$-SBA-15 (2.35 g) was dispersed in $80 \mathrm{~mL}$ methanol, and $20 \mathrm{~mL}$ salicylaldehyde/methanol solution $(0.2 \mathrm{~mol} / \mathrm{L}, 0.488 \mathrm{~g}$ salicylaldehyde) was added to form a light-yellow solution. After stirring at $30{ }^{\circ} \mathrm{C}$ for $6 \mathrm{~h}$, the mixture was heated to $50{ }^{\circ} \mathrm{C}$ and $10 \mathrm{~mL} \mathrm{Cu}\left(\mathrm{NO}_{3}\right)_{2} /$ methanol solution $(0.1 \mathrm{~mol} / \mathrm{L})$ was added dropwise to form a green solution. The reaction mixture was stirred for a further $12 \mathrm{~h}$. The solid was then collected by suction filtration, washed with methanol and water, and finally dried at $80{ }^{\circ} \mathrm{C}$ overnight. The content of $\mathrm{Cu}$ was $0.101 \mathrm{mmol} / \mathrm{g}$ (ICP-AES).

\subsection{Catalyst characterization}

Low-angle X-ray diffraction (XRD) patterns were recorded with a Rigaku X-ray diffractometer with nickel-filtered $\mathrm{Cu} K_{\alpha}$ radiation at $40 \mathrm{kV}$ and $30 \mathrm{~mA}$. The samples were scanned in the range $2 \theta=0.7^{\circ}-5.0^{\circ}$. The Fourier transform infrared (FT-IR) spectra were collected on a Nicolet IS10 spectrometer (Thermo). Field emission scanning electron microscope (FESEM) images of the samples were obtained with an HITACHIS4800 FSEM and the particle sizes were measured using Adobe Photoshop software. The channel structures were observed on a JEM-2010-UHR transmission electron microscope (TEM) and ultraviolet-visible (UV-Vis) spectra were recorded on a Perkin Elmer UV-Vis spectrophotometer, Lambda 950, in the region of 200-800 nm. A BELSORP II adsorption instrument was used to determine the specific surface area, pore volume, and pore size. The specific surface area $\left(A_{\mathrm{BET}}\right)$ was calculated by the BET method, the pore volume $\left(V_{\text {total }}\right)$ was calculated at the relative pressure of 0.99 and the pore size distributions and $D_{\text {peak }}$ were measured by the BJH method from the adsorption branch of the isotherms. Thermo gravimetric analysis (TGA) was carried out on a Netzsch STA409 instrument. CHN element analysis was carried out using a Perkin-Elmer 2400 instrument. The content of $\mathrm{Cu}$ was measured by inductive coupled high frequency plasma atomic emission spectrometry (ICP-AES) analysis.

\subsection{Catalytic activity test}

The oxidation of styrene was conducted in a $100-\mathrm{mL}$ stainless-steel high-pressure autoclave (Parr, USA). The catalyst, water, $\mathrm{H}_{2} \mathrm{O}_{2}$ (30 wt\%), and styrene (5.200 g) were added into the vessel and it was then heated to $100{ }^{\circ} \mathrm{C}$ with a stirring speed of $800 \mathrm{r} / \mathrm{min}$. After the reaction was complete, the mixture was centrifuged ( $8000 \mathrm{r} / \mathrm{min}, 2 \mathrm{~min}$ ) and the solid was washed with EtOAc. The combined organic phases were dried over anhydrous $\mathrm{MgSO}_{4}$, and analyzed on a gas-chromatograph (GC2014, Shimadzu Instruments, Japan) equipped with DB-5 capillary column $(30 \mathrm{~m} \times 0.25 \mathrm{~mm} \times 0.25 \mu \mathrm{m})$. The recovered catalyst was washed with acetone, alcohol, and water, and dried at $100{ }^{\circ} \mathrm{C}$ overnight before reuse.

\section{Results and discussion}

\subsection{Catalyst characterization}

The low-angle XRD patterns of $\mathrm{NH}_{2}-\mathrm{SBA}-15$ and $\mathrm{Cu}-\mathrm{SBA}-15$

\subsubsection{Preparation of $\mathrm{Cu}-\mathrm{SBA}-15$}


are depicted in Fig. 1(a). The pattern of $\mathrm{NH}_{2}$-SBA-15 shows an intense diffraction indexed to the (100) plane, which indicates the typical mesoporous structure of SBA-15. The other two small characteristic peaks are not clearly observed, probably because the use of the silane coupling agent negatively affected the formation of micelles and resulted in an irregularity of the pores. FT-IR spectra of SBA-15, NH2-SBA-15, Schiff-baseSBA-15, and Cu-SBA-15 are shown in Fig. 1(b). The peaks at $467,799,1081$, and $1230 \mathrm{~cm}^{-1}$ indicate the characteristic absorption of $\mathrm{O}-\mathrm{Si}-\mathrm{O}$ bonds and the peak at $946 \mathrm{~cm}^{-1}$ indicates the existence of $\mathrm{Si}-\mathrm{OH}$. The strong peak around $1632 \mathrm{~cm}^{-1}$ in all the samples results largely from the bending vibration of adsorbed water, and the broad band observed between 3700 and $2800 \mathrm{~cm}^{-1}$ is attributed to the $-\mathrm{OH}$ stretching vibration of water adsorbed on the surface of the catalyst. The presence of the $-\mathrm{NH}_{2}$ stretching vibration at $3250 \mathrm{~cm}^{-1}$, the bending vibration at $1510 \mathrm{~cm}^{-1}$ and the $\mathrm{N}-\mathrm{H}$ bending vibration at $668 \mathrm{~cm}^{-1}$ confirm the incorporation of the amino groups. The absorption

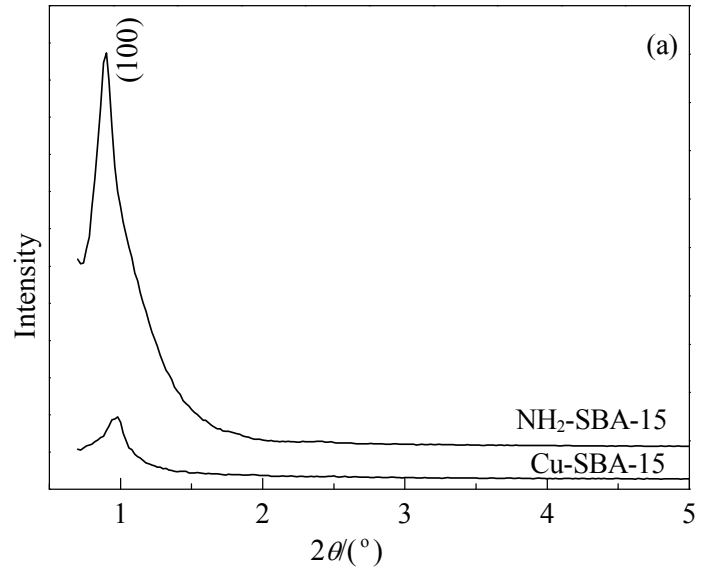

at about $1510 \mathrm{~cm}^{-1}$ can be observed in both Schiff-base-SBA-15 and $\mathrm{Cu}-\mathrm{SBA}-15$ but has a low intensity, indicating the occurrence of the condensation of salicylaldehyde with the amino groups on the surface of $\mathrm{NH}_{2}-\mathrm{SBA}-15$. Generally, a weak absorption peak of $\mathrm{C}=\mathrm{N}$ stretching vibration should occur around $1640-1650 \mathrm{~cm}^{-1}$ for the Schiff-base-SBA-15. However, this peak is overlapped by the stretching vibration absorption of $\mathrm{H}_{2} \mathrm{O}$. Notably, comparison of the IR spectra of Cu-SBA-15 and Schiff-base-SBA-15 indicates the presence of a new adsorption peak around $1387 \mathrm{~cm}^{-1}$ in $\mathrm{Cu}-\mathrm{SBA}-15$. This new peak may result from the red shift of the $\mathrm{C}=\mathrm{N}$ stretching vibration absorption due to coordination to copper ions.

The FESEM image of $\mathrm{NH}_{2}$-SBA-15 is presented in Fig. 2(a). The sample shows a typical rod-like morphology of SBA-15. As shown in Fig. 2(b), the diameters of most particles are typically in the range of $600-700 \mathrm{~nm}$ and the average particle size is $740 \mathrm{~nm}$. The TEM images of $\mathrm{NH}_{2}-\mathrm{SBA}-15$ and Cu-SBA-15 are shown in Fig. 2(c) and (d), respectively,

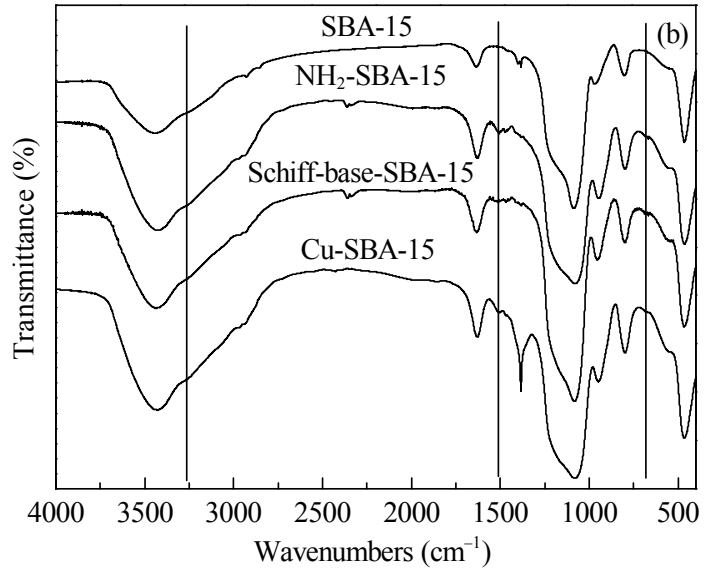

Fig. 1. (a) XRD patterns of $\mathrm{NH}_{2}$-SBA-15 and Cu-SBA-15. (b) FT-IR spectra of SBA-15, $\mathrm{NH}_{2}$-SBA-15, Schiff-base-SBA-15, and Cu-SBA-15.
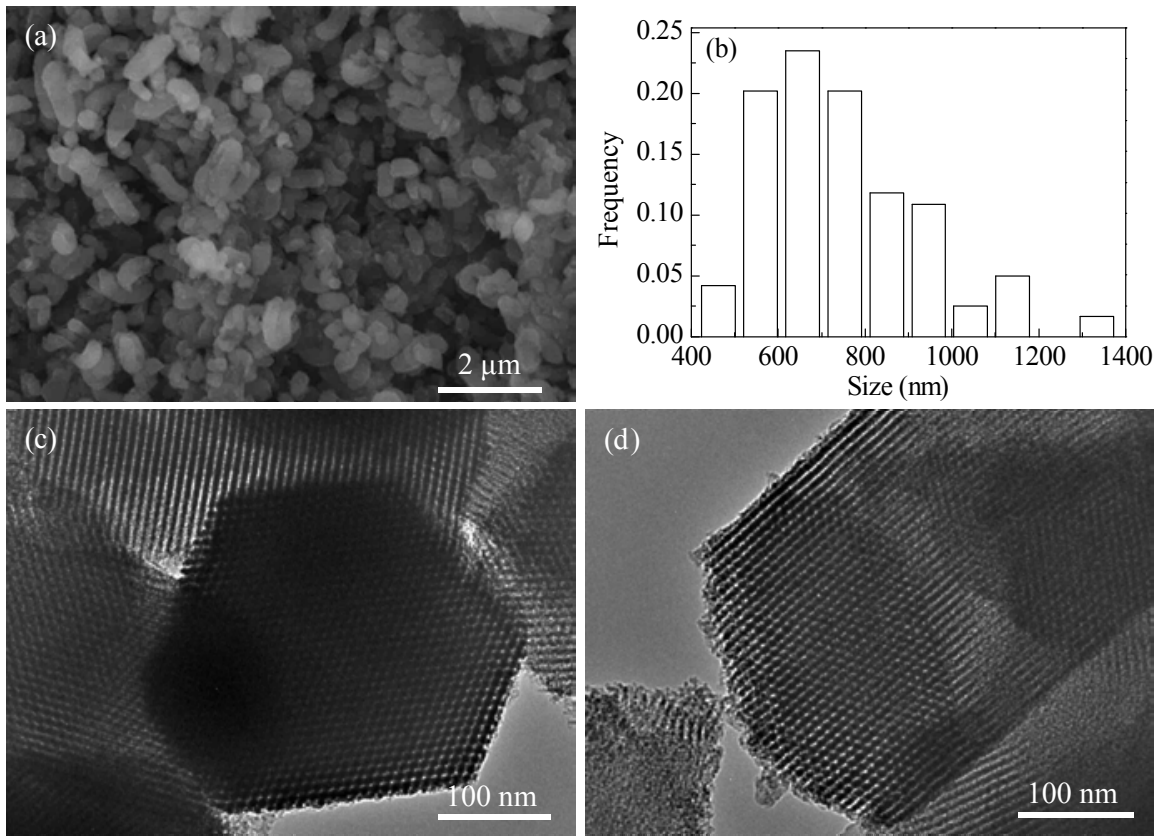

Fig. 2. (a) FESEM image of $\mathrm{NH}_{2}$-SBA-15; (b) Particle size distribution of the sample; (c) TEM image of $\mathrm{NH}_{2}$-SBA-15; (d) TEM image of Cu-SBA-15. 


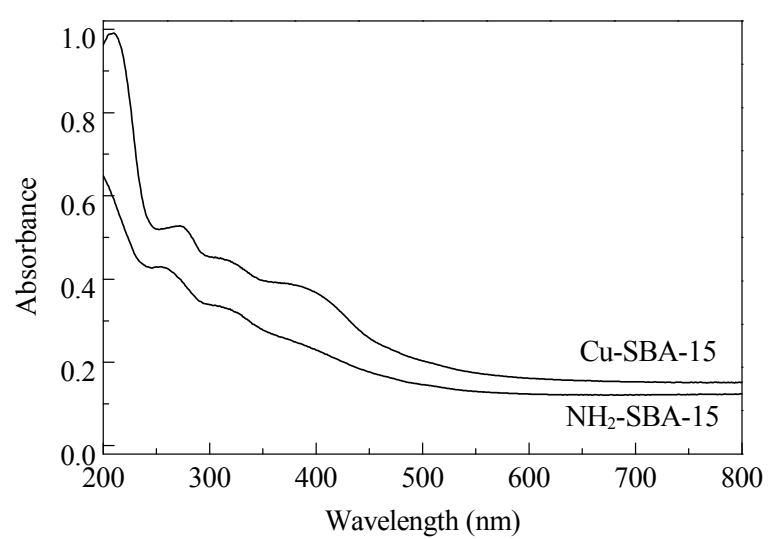

Fig. 3. UV-Vis spectra of $\mathrm{NH}_{2}$-SBA-15and $\mathrm{Cu}-\mathrm{SBA}-15$.

and provide a direct visualization of well-ordered hexagonal arrays of 1D mesoporous channels for both types of sample. Some pore walls in the sample have collapsed, which accounts for the absence of the two low-intensity characteristic peaks in the XRD patterns.

Figure 3 shows the UV-Vis spectra of $\mathrm{NH}_{2}-\mathrm{SBA}-15$ and $\mathrm{Cu}-\mathrm{SBA}-15$. In contrast to the spectrum of $\mathrm{NH}_{2}$-SBA-15, a typical metal-ligand band around $390 \mathrm{~nm}$ is observed for Cu-SBA-15 [24], indicating the successful anchoring of the $\mathrm{Cu}$ (II) Schiff-base complex to the SBA-15 matrix.

As shown in Fig. 4, the $\mathrm{N}_{2}$ adsorption-desorption isotherm for $\mathrm{NH}_{2}-\mathrm{SBA}-15$ is type IV with an H1-type hysteresis loop, typical for mesoporous materials with cylindrical porous channels. The Cu-SBA-15 sample maintains the characteristics of type IV yet with an $\mathrm{H} 2$ hysteresis loop, probably because of a partial blocking of the pores. The size distribution curves show similar peaks at $5.41 \mathrm{~nm}$ while the peak for Cu-SBA-15 has a lower intensity and is broader. The textural properties of $\mathrm{NH}_{2}-\mathrm{SBA}-15$ and Cu-SBA-15 are summarized in Table 1 . The $A_{\mathrm{BET}}$ and pore volumes of Cu-SBA-15 are slightly lower than those of $\mathrm{NH}_{2}$-SBA-15. We consider that these results reflect the introduction of the Schiff-base-coordinated copper complex on the material, leading to the blockage of some pores.

The TGA results for $\mathrm{NH}_{2}-\mathrm{SBA}-15$ and $\mathrm{Cu}-\mathrm{SBA}-15$ are illustrated in Fig. 5. For both $\mathrm{NH}_{2}-\mathrm{SBA}-15$ and Cu-SBA-15, the weight loss below $100{ }^{\circ} \mathrm{C}$ is mainly attributed to the loss of adsorbed water. The subsequent weight loss from $200-350{ }^{\circ} \mathrm{C}$

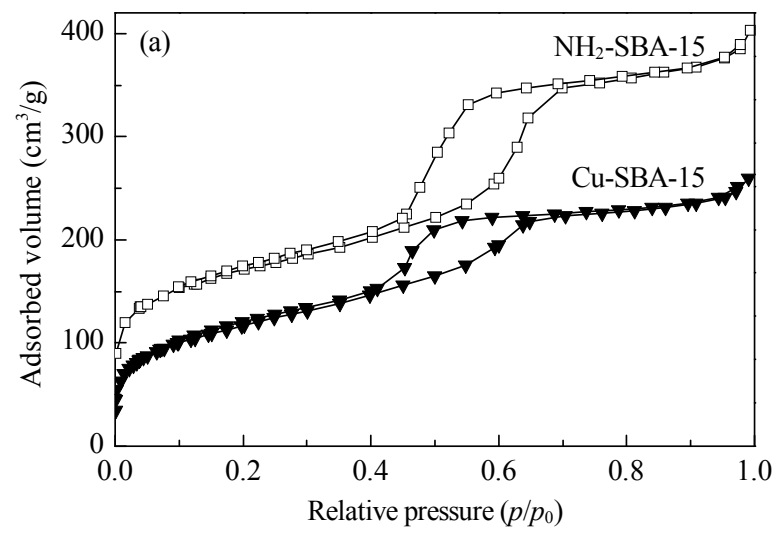

Table 1

Textural properties of $\mathrm{NH}_{2}$-SBA-15 and Cu-SBA-15.

\begin{tabular}{lccc}
\hline Sample & $A_{\text {BET }} /\left(\mathrm{m}^{2} / \mathrm{g}\right)$ & $V_{\text {total }} /\left(\mathrm{cm}^{3} / \mathrm{g}\right)$ & $D_{\text {peak }} / \mathrm{nm}$ \\
\hline $\mathrm{NH}_{2}$-SBA-15 & 443 & 0.54 & 5.41 \\
$\mathrm{Cu}-$ SBA-15 & 423 & 0.34 & 5.41 \\
\hline
\end{tabular}

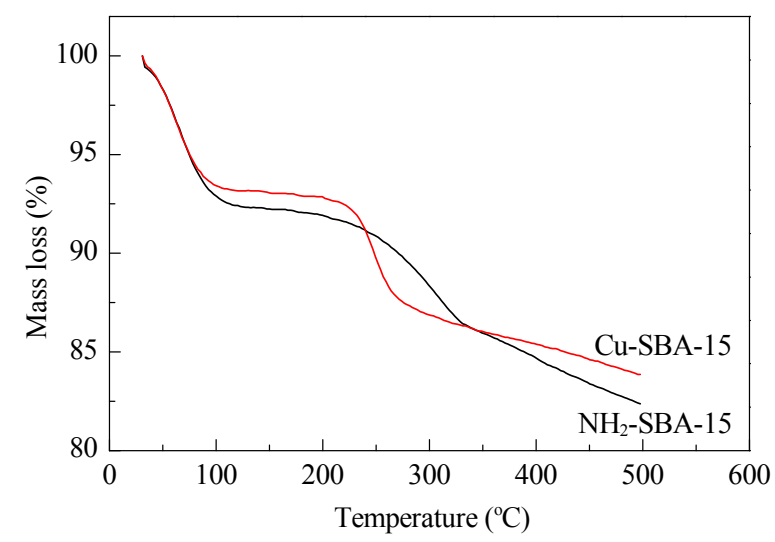

Fig. 5. TG curves of $\mathrm{NH}_{2}-\mathrm{SBA}-15$ and $\mathrm{Cu}-\mathrm{SBA}-15$.

is due to the decomposition of the amino groups and the Schiff bases. The weight loss of Cu-SBA-15 occurs at lower temperatures, relative to $\mathrm{NH}_{2}-\mathrm{SBA}-15$, because of the higher molecular mass of the Schiff-bases compared with that of the amino groups. Finally, the decomposition of the aminopropyl groups caused the weight loss at temperatures above $350{ }^{\circ} \mathrm{C}$.

\subsection{Optimization of reaction conditions}

\subsubsection{Effect of the reaction time}

Figure 6(a) shows the effect of reaction time on styrene oxidation at $100{ }^{\circ} \mathrm{C}$ using $0.300 \mathrm{~g} \mathrm{Cu}$-SBA-15 as the catalyst and 1.5 equiv. $\mathrm{H}_{2} \mathrm{O}_{2}$ ( $10 \mathrm{wt} \%$ aqueous) as the oxidant. The styrene conversion increased with reaction duration while the selectivity for benzaldehyde declined slowly. The conversion reached $55.4 \%$ and the selectivity was $80 \%$ after $8 \mathrm{~h}$. The conversion of styrene further increased after $9 \mathrm{~h}$, but styrene then underwent polymerization, resulting in a considerable decrease in selectivity. This behavior is because the $\mathrm{H}_{2} \mathrm{O}_{2}$ was completely consumed after $9 \mathrm{~h}$, and the residual styrene underwent polymerization under these conditions.

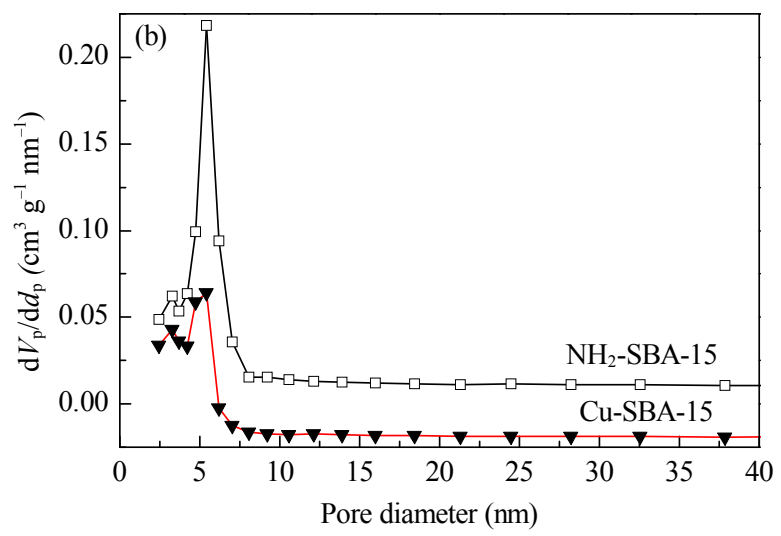

Fig. 4. $\mathrm{N}_{2}$ adsorption-desorption isotherms (a) and corresponding mesopore size distribution curves (b) of $\mathrm{NH}_{2}-\mathrm{SBA}-15$ and $\mathrm{Cu}-\mathrm{SBA}-15$. 


\subsubsection{Effect of the reaction temperature}

Figure 6(b) shows the effect of reaction temperature on styrene oxidation using $0.300 \mathrm{~g} \mathrm{Cu}-\mathrm{SBA}-15$ as the catalyst and 1.5 equiv. $\mathrm{H}_{2} \mathrm{O}_{2}$ ( $10 \mathrm{wt} \%$ aqueous) as the oxidant for $8 \mathrm{~h}$. It is clear that the conversion of styrene rapidly decreased with a decrease in the reaction temperature. When the reaction was performed at $80{ }^{\circ} \mathrm{C}$, the conversion of styrene was only $6.8 \%$. However, the selectivity was much higher at a lower reaction temperature because the rate of benzaldehyde oxidation to benzoic acid is also lower. When the reaction was conducted at $100{ }^{\circ} \mathrm{C}$ for $8 \mathrm{~h}$, the conversion of styrene reached $55.4 \%$ and the selectivity for benzaldehyde was up to $79.3 \%$.

\subsubsection{Effect of the amount of $\mathrm{H}_{2} \mathrm{O}_{2}$}

The effect of the amount of $\mathrm{H}_{2} \mathrm{O}_{2}$ used was investigated by conducting the reactions at $100{ }^{\circ} \mathrm{C}$ for $8 \mathrm{~h} . \mathrm{H}_{2} \mathrm{O}_{2} \quad(10 \mathrm{wt} \%$ aqueous) was used in the presence of $0.300 \mathrm{~g} \mathrm{Cu}-\mathrm{SBA}-15$ and 17.167 $\mathrm{g} \mathrm{H}_{2} \mathrm{O}$. As shown in Fig. 6(c), the conversion of styrene gradually increases with an increase in the amount of $\mathrm{H}_{2} \mathrm{O}_{2}$ used. When 2 equiv. $\mathrm{H}_{2} \mathrm{O}_{2}$ was used, the conversion of styrene was $70.6 \%$ and the selectivity for benzaldehyde was $79.6 \%$. When 2.5 equiv. $\mathrm{H}_{2} \mathrm{O}_{2}$ was used, the conversion increased to $84.5 \%$, but the selectivity dropped sharply to $65.4 \%$. A further increase in the amount of $\mathrm{H}_{2} \mathrm{O}_{2}$ employed resulted in no increase in styrene conversion, and a much lower selectivity. This can be ascribed to the remaining $\mathrm{H}_{2} \mathrm{O}_{2}$ promoting the further oxidation of benzaldehyde to benzoic acid. Overall, the use of 2 equiv. $\mathrm{H}_{2} \mathrm{O}_{2}$ for the catalytic oxidation of styrene is suitable.

\subsubsection{Effect of the amount of $\mathrm{H}_{2} \mathrm{O}$}

Since there is no co-solvent used in the reaction, the amount of $\mathrm{H}_{2} \mathrm{O}$ added in the reaction determines the $\mathrm{H}_{2} \mathrm{O}_{2}$ concentration. We investigated the effect of $\mathrm{H}_{2} \mathrm{O}$ by conducting the reactions at $100{ }^{\circ} \mathrm{C}$ for $8 \mathrm{~h}$ with various amounts of $\mathrm{H}_{2} \mathrm{O}$ in the presence of $0.300 \mathrm{~g} \mathrm{Cu}-\mathrm{SBA}-15$ and 2 equiv. $\mathrm{H}_{2} \mathrm{O}_{2}$. The results are shown in Fig. 6(d). It is obvious that the conversion of styrene is the highest with no extra $\mathrm{H}_{2} \mathrm{O}$ added. The addition of $\mathrm{H}_{2} \mathrm{O}$ slowed the oxidation process and led to a low conversion.

\subsubsection{Effect of catalyst loading}

Figure 6(e) shows the influence of catalyst loading. The conversion of styrene and the selectivity for benzaldehyde were $84.4 \%$ and $83.9 \%$, respectively, when the reaction was conducted at $100{ }^{\circ} \mathrm{C}$ for $8 \mathrm{~h}$ with 2 equiv. $\mathrm{H}_{2} \mathrm{O}_{2}$ and $0.200 \mathrm{~g}$ Cu-SBA-15. An increase in the amount of catalyst used has little effect on the reaction. However, when the amount of the catalyst was reduced to 0.150 or $0.100 \mathrm{~g}$, the reaction mixture became viscous after $8 \mathrm{~h}$, probably because of the formation of styrene oligomers. A high loading of the catalyst is required to accelerate the rate of the oxidation process and prevent styrene polymerization.

Based on the above results, we obtained the optimum conditions as follows: the reaction should be carried out at $100{ }^{\circ} \mathrm{C}$ for $8 \mathrm{~h}$ using 2.0 equiv $\mathrm{H}_{2} \mathrm{O}_{2}$ (30 wt\% aqueous) and $3.8 \mathrm{wt} \%$ $\mathrm{Cu}$-SBA-15 catalyst. The conversion of styrene obtained was up to $84.4 \%$, and the selectivity for benzaldehyde was $83.9 \%$. The TOF of the catalyst was $261.1 \mathrm{~h}^{-1}$. Benzoic acid was the only by-product and the formation of styrene oxide was not observed. At the optimum conditions, we found that this heterogeneous catalyst gave competitive results compared with other reported catalysts in terms of conversion and selectivity and, in addition, a high TOF was obtained (Table 2). When
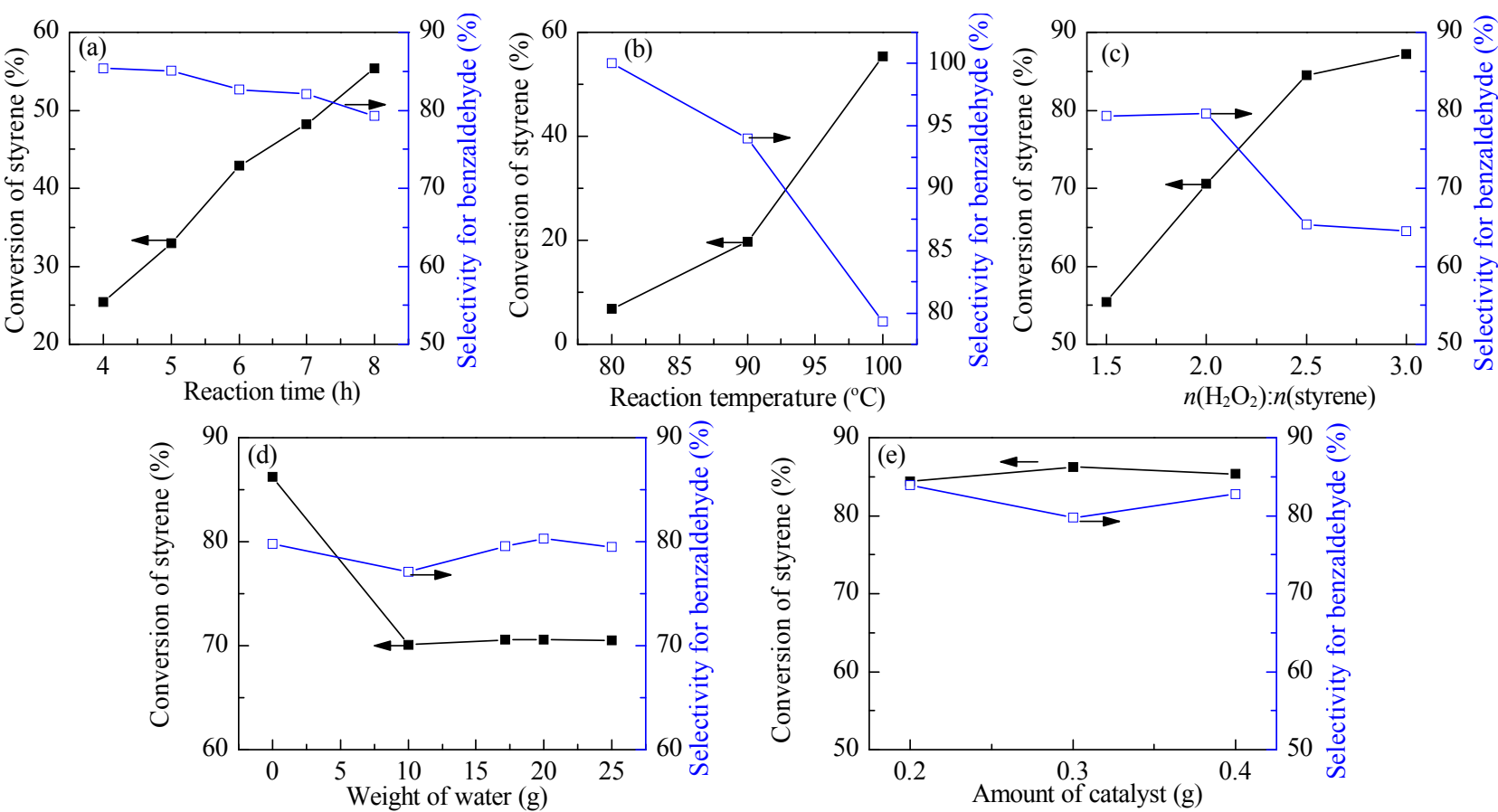

Fig. 6. Effect of reaction time (a), temperature (b), amount of $\mathrm{H}_{2} \mathrm{O}_{2}$ (c), weight of $\mathrm{H}_{2} \mathrm{O}$ (d), and the amount of catalyst (e) on the oxidation of styrene to benzaldehyde. Other reaction conditions: (a) $100{ }^{\circ} \mathrm{C}$, $n$ (styrene): $n\left(\mathrm{H}_{2} \mathrm{O}_{2}\right)=1: 1.5,10 \mathrm{wt} \% \mathrm{H}_{2} \mathrm{O}_{2}, 0.3 \mathrm{~g}$ catalyst, $800 \mathrm{r} / \mathrm{min}$; (b) $8 \mathrm{~h}, n$ (styrene): $n\left(\mathrm{H}_{2} \mathrm{O}_{2}\right)=$ 1:1.5, $10 \mathrm{wt} \% \mathrm{H}_{2} \mathrm{O}_{2}, 0.3 \mathrm{~g}$ catalyst, $800 \mathrm{r} / \mathrm{min}$; (c) $100{ }^{\circ} \mathrm{C}, 8 \mathrm{~h}, 10 \mathrm{wt} \% \mathrm{H}_{2} \mathrm{O}_{2}, 0.3 \mathrm{~g}$ catalyst, $800 \mathrm{r} / \mathrm{min}$; (d) $100{ }^{\circ} \mathrm{C}, 8 \mathrm{~h}, n\left(\right.$ styrene):n( $\left.\mathrm{H}_{2} \mathrm{O}_{2}\right)=1: 2,0.3 \mathrm{~g}$ catalyst, $800 \mathrm{r} / \mathrm{min}$; (e) $100{ }^{\circ} \mathrm{C}, 8 \mathrm{~h}, n$ (styrene): $n\left(\mathrm{H}_{2} \mathrm{O}_{2}\right)=1: 2,30 \mathrm{wt} \% \mathrm{H}_{2} \mathrm{O}_{2}, 800 \mathrm{r} / \mathrm{min}$. 
Table 2

Activity of the supported metal complex catalysts.

\begin{tabular}{|c|c|c|c|c|c|c|c|}
\hline \multirow{2}{*}{ Catalyst } & \multirow{2}{*}{$\begin{array}{c}\text { Conversion } \\
(\%)\end{array}$} & \multicolumn{2}{|c|}{ Selectivity (\%) } & \multirow{2}{*}{ TOF $\left(h^{-1}\right)$} & \multirow{2}{*}{ Oxidant } & \multirow{2}{*}{ Solvent } & \multirow{2}{*}{ Refrence } \\
\hline & & Benzaldehyde & Styreneoxide & & & & \\
\hline Cu-SBA-15 & 84.4 & 83.9 & 0 & 261.1 & $\mathrm{H}_{2} \mathrm{O}_{2}$ & $\mathrm{H}_{2} \mathrm{O}$ & this work \\
\hline VO-Salen-SBA & 84.1 & 83.3 & 11.9 & 67.4 & $\mathrm{H}_{2} \mathrm{O}_{2}$ & $\mathrm{CH}_{3} \mathrm{CN}$ & 25 \\
\hline Cu-Salen-SBA & 96.9 & 45.2 & 13.5 & 134.6 & $\mathrm{H}_{2} \mathrm{O}_{2}$ & $\mathrm{CH}_{3} \mathrm{CN}$ & 25 \\
\hline Co- $\left[\mathrm{H}_{4}\right]$ Salen-SBA & 78.5 & 43.6 & 54.1 & 196.0 & Air & $\mathrm{CH}_{3} \mathrm{CN}$ & 28 \\
\hline SBA-Fe(acac:salen) & 45.0 & 99.0 & 0 & 0.24 & $\mathrm{H}_{2} \mathrm{O}_{2}$ & $\mathrm{CH}_{3} \mathrm{CN}$ & 26 \\
\hline SBA-VO(acac) & 84.0 & 96.0 & 0 & 9.5 & $\mathrm{H}_{2} \mathrm{O}_{2}$ & $\mathrm{CH}_{3} \mathrm{CN}$ & 27 \\
\hline PS-NH $2-\mathrm{Cu}$-Sal & 53.0 & 52.0 & 48.0 & 12.6 & TBHP & $\mathrm{CH}_{3} \mathrm{CN}$ & 29 \\
\hline Polymer supported cobalt complex & 100 & 89.0 & 11.0 & 50.0 & $\mathrm{H}_{2} \mathrm{O}_{2}$ & $\mathrm{H}_{2} \mathrm{O}$ & 30 \\
\hline
\end{tabular}

acetonitrile was used as a solvent under these conditions, the conversion of styrene reached up to $96.7 \%$, while the selectivity for benzaldehyde was only $58.3 \%$ because of the formation of several by-products including benzoic acid (16.7\%), phenylacetaldehyde (15.8\%) and phenylethylene glycol (9.2\%).

\subsection{Catalyst recycling}

Recyclability is one of the most important benefits of supported catalysts and makes them attractive for commercial applications. We therefore investigated the recovery and recyclability of the supported catalyst used. The results are summarized in Table 3 and show that the Cu-SAB-15 catalyst could be successfully used three times without significant loss of the activity. The main product and by-product were benzaldehyde and benzoic acid, respectively, and no styrene oxide was detected in any of the cases. The slight decrease in selectivity for the recovered catalyst is probably due to residual organics on the catalyst impeding the desorption of benzaldehyde from the catalytic centers, leading to over-oxidation to benzoic acid.

\subsection{Mechanism of styrene oxidation}

Styrene can generally be oxidized to benzaldehyde via two distinct pathways using a copper(II) Schiff-base complex as a catalyst (Scheme 1) [27]. The first path involves a radical mechanism. One molecule of $\mathrm{H}_{2} \mathrm{O}_{2}$ adsorbed on the catalyst first decomposes to two hydroxyl radicals. These radicals then add to the $\mathrm{C}=\mathrm{C}$ bond of styrene to form phenylethylene glycol, which then undergoes oxidative cleavage to form benzaldehyde and formaldehyde. Benzaldehyde is readily oxidized to benzoic acid. Alternatively, styrene first reacts with the active $\mathrm{H}_{2} \mathrm{O}_{2}$ molecule to form styrene oxide, which may further transform

Table 3

Experimental results on the recycling of $\mathrm{Cu}-\mathrm{SBA}-15$.

\begin{tabular}{lcccc}
\hline \multirow{2}{*}{ Cycle } & $\begin{array}{c}\text { Styrene } \\
\text { Conversion }^{\mathrm{a}}(\%)\end{array}$ & \multicolumn{3}{c}{ Selectivity $^{\mathrm{b}}(\%)$} \\
\cline { 3 - 5 } & 84.4 & 83.9 & 16.1 & 0 \\
\hline 1 & 86.9 & 81.6 & 18.4 & 0 \\
2 & 85.7 & 81.2 & 18.8 & 0 \\
\hline
\end{tabular}

a Styrene conversion calculated via GC analysis.

b Product selectivity calculated via GC analysis.

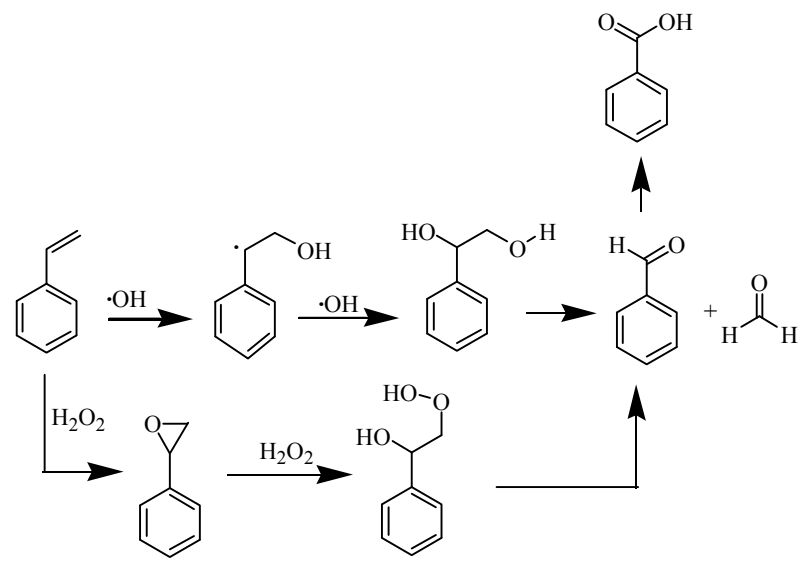

Scheme 1. Plausible reaction mechanism of styrene oxidation.

to a hydroxyl-hydroxylperoxistyrene intermediate upon nucleophilic attack by another molecule of $\mathrm{H}_{2} \mathrm{O}_{2}$. Carbon bond cleavage of this unstable intermediate then produces benzaldehyde and formaldehyde. Since the intermediate styrene oxide was not detected during the course of the reaction, we concluded that the catalytic oxidation of styrene with Cu-SBA-15 follows the first pathway. In addition, as can be seen from the reaction mechanism, 2 equiv. $\mathrm{H}_{2} \mathrm{O}_{2}$ is required for styrene oxidation to benzaldehyde. This is in good agreement with our experimental results, which showed that the conversion was generally low when less than 2 equiv. of $\mathrm{H}_{2} \mathrm{O}_{2}$ was used, while a high conversion of styrene was observed, with decreased selectivity if more $\mathrm{H}_{2} \mathrm{O}_{2}$ was employed.

\section{Conclusions}

We prepared $\mathrm{NH}_{2}$-SBA-15 using a one-pot co-condensation method, and anchored the copper(II) Schiff-base complex to afford a solid catalyst, Cu-SBA-15, for the selective oxidation of styrene to benzaldehyde. The highest conversion of styrene reached $84.4 \%$, the selectivity for benzaldehyde was up to $83.9 \%$, and the TOF of the catalyst was $261.1 \mathrm{~h}^{-1}$. The catalyst could be used three times without significant loss of activity. The distribution of amino groups on the material prepared by the one-pot co-condensation method may be better than is the case with a post-synthesis grafting method. Therefore, the active species could be well distributed on the surface of the prepared Cu-SBA-15 catalyst, leading to a higher catalytic activity. 


\title{
Graphical Abstract
}

Chin. J. Catal., 2014, 35: 1716-1726 doi: 10.1016/S1872-2067(14)60131-5

Catalytic oxidation of styrene to benzaldehyde over a copper Schiff-base/SBA-15 catalyst

Xuecheng Zhu, Ruwei Shen, Lixiong Zhang*

Nanjing Tech University

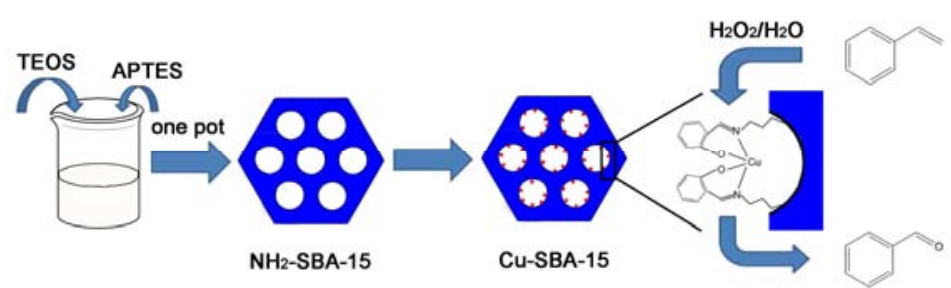

A Cu-SBA-15 catalyst was prepared by immobilizing a copper Schiff-base complex onto an amino-modified mesoporous material SBA-15, synthesized via a one-pot co-condensation method. The catalyst was used for the oxidation of styrene to benzaldehyde in an aqueous medium.

\section{References}

[1] Kirk-Othmer. Encyclopedia of Chemical Technology. 5th ED. John Wiley \& Sons, Inc. 2007, 3: 590

[2] Wang Y, Qiao X. Fin Chem Interm (王毅, 乔旭. 精细化工中间体), 2005, 35: 44

[3] Tang S W. [PhD Dissertation]. Chengdu: Sichuan University (唐盛 伟. [博士学位论文]. 成都: 四川大学), 2005

[4] Zhang X, Zhang L X, Xu N P. Petochem Technol (张旭, 张利雄, 徐南 平. 石油化工), 2009, 38: 215

[5] Chen D D, Li N K, Sun P, Kong Y. Chin J Catal (陈丹丹, 李年凯, 孙 鹏，孔岩. 催化学报), 2009, 30: 643

[6] Shi F, Tse M K, Pohl M M, Brückner A, Zhang S M, Beller M. Angew Chem Int Ed, 2007, 46: 8866

[7] Lu X H, Lei J, Zhou D, Fang S Y, Dong Y L, Xia Q H. Indian J Chem A, 2010, 49: 1586

[8] Adam F, Iqbal A. Microporous Mesoporous Mater, 2011, 141: 119

[9] Pardeshi S K, Pawar R Y.J Mol Catal A, 2011, 334: 35

[10] Rajabi F, Karimi N, Saidi M R, Primo A, Varma R S, Luque R. Adv Synth Catal, 2012, 354: 1707

[11] Zhou L, Madix R J. Surf Sci, 2009, 603: 1751

[12] Polshettiwar V, Varma R S. Org Biomol Chem, 2009, 7: 37

[13] Zhang X, Zeng C F, Zhang L X, Xu N P. Kinet Catal, 2009, 50: 199

[14] Xiao Z W, He H Y. Chin J Catal (肖质文, 何红运. 催化学报), 2010, 31: 705

[15] Hu J L, Li K X, Li W, Ma F Y, Guo Y H. Appl Catal A, 2009, 364: 211

[16] Patel A, Pathan S. Ind Eng Chem Res, 2012, 51: 732

[17] Qiu M, Liu G S, Yao X Q, Guo M Y, Pan G Z, Zheng Z. Chin J Catal (仇 敏, 刘国生, 姚小泉, 郭明彦, 潘桂芝, 郑卓. 催化学报), 2001，22: 78

[18] Pasc-Banu A, Sugisaki C, Gharsa T, Marty J D, Gascon I, Krämer M,
Pozzi G, Desbat B, Quici S, Rico-Lattes I, Mingotaud C. Chem Eur J, 2005, 11: 6032

[19] Silva M, Freire C, de Castro B, Figueiredo J L. J Mol Catal A, 2006, 258: 327

[20] Kuźniarska-Biernacka I, Rodrigues B, Carvalho M A, Neves I C, Fonseca A M. Appl Organomet Chem, 2012, 26: 44

[21] Maurya M R, Saini P, Kumar A, Costa Pessoa J. Eur J Inorg Chem, 2011, 31: 4846

[22] Kuźniarska-Biernacka I, Fonseca A M, Neves I C. Inorg Chim Acta, 2013, 394: 591

[23] Jana S, Dutta B, Bera R, Koner S. Langmuir, 2007, 23: 2492

[24] Yang Y, Guan J Q, Qiu P P, Kan Q B. Appl Surf Sci, 2010, 256: 3346

[25] Yang Y, Zhang Y, Hao S J, Guan J Q, Ding H, Shang F P, Qiu P P, Kan Q B. Appl Catal A, 2010, 381: 274

[26] Anand N, Reddy K H P, Swapna V, Rao K S R, Burri D R. Microporous Mesoporous Mater, 2011, 143: 132

[27] Anand N, Reddy K H P, Rao K S R, Burri D R. Catal Lett, 2011, 141: 1355

[28] Yang Y, Zhang Y, Hao S J, Kan Q B. Chem Eng J, 2011, 171: 1356

[29] Islam S M, Mondal P, Mukherjee S, Roy A S, Bhaumik A. Polym Adv Technol, 2011, 22: 933

[30] Tamami B, Ghasemi S. Appl Catal A, 2011, 393: 242

[31] Dai X, Gao B J, Lei H B. Chin J Catal (代新, 高保娇, 雷海波. 催化学 报), 2012, 33: 885

[32] Sripathi V G P, Mojet B L, Nijmeijer A, Benes N E. Microporous Mesoporous Mater, 2013, 172: 1

[33] Lim M H, Stein A. Chem Mater, 1999, 11: 3285

[34] Macquarrie D J, Jackson D B. Chem Commun, 1997, 18: 1781

[35] Wang X G, Chan J C C, Tseng Y H, Cheng S F. Microporous Mesoporous Mater, 2006, 95: 57

[36] Wang X G, Lin K S K, Chan J C C, Cheng S F. J Phys Chem B, 2005, 109: 1763

\section{SBA-15负载的 Cu(II)席夫碱配合物催化的苯乙烯氧化反应制备苯甲醛}

\author{
朱学成, 沈如伟, 张利雄 ${ }^{*}$
}

南京工业大学化学化工学院材料化学工程国家重点实验室, 江苏南京210009 
子笁 SBA-15 ( $\mathrm{NH}_{2}$-SBA-15), 再利用其中氨基与水杨醛的缩合反应制备 SBA-15固载的席夫碱, 该席夫碱与 $\mathrm{Cu}\left(\mathrm{NO}_{3}\right)_{2}$ 溶液反应最终 制成固定于SBA-15的 $\mathrm{Cu}(\mathrm{II})$ 席夫碱配合物多相催化剂Cu-SBA-15. 采用X射线衍射、红外光谱仪、紫外可见分光光度计、场发射 电镜、透射电镜、 $\mathrm{N}_{2}$ 吸附-脱附、元素分析、原子发射光谱和热重分析对催化剂进行了表征, 并将此催化剂用于无有机溶剂条件 下催化氧化苯乙烯制备苯甲醛, 考察了反应时间、反应温度、 $\mathrm{H}_{2} \mathrm{O}_{2}$ 用量、水的用量、催化剂用量对反应的影响. 当反应温度为 $100{ }^{\circ} \mathrm{C}$, 反应时间 $8 \mathrm{~h}, \mathrm{H}_{2} \mathrm{O}_{2}$ 与苯乙烯的摩尔比为 $2: 1$, 不额外添加溶剂, 且催化剂用量为 $3.8 \mathrm{wt} \%$ 时, 苯乙烯的转化率最高为 $84.4 \%$, 苯甲醛选择性为 $83.9 \%$, 催化剂的TOF值为 $261.1 \mathrm{~h}^{-1}$, 并且重复使用 3 次后活性没有明显下降. 规则的孔道、较大的比表面积以及分 布均匀的活性中心可能是催化剂活性提高的原因.

关键词: 铜席夫碱配合物; 氨基功能化; SBA-15; 苯乙烯氧化; 苯甲酫; 杂相催化

收稿日期: 2014-03-01. 接受日期: 2014-04-28. 出版日期: 2014-10-20.

*通讯联系人. 电话: (025)83172265; 传真: (025)83172263; 电子信箱: lixzhang@njtech.edu.cn 本文的英文电子版由Elsevier出版社在ScienceDirect上出版(http://www.sciencedirect.com/science/journal/18722067).

\section{1. 前言}

苯甲醛是一种重要的有机化学中间体, 广泛应用于 香料、医药、染料等 ${ }^{[1]}$. 现今工业上制备苯甲醛的工艺 主要有苯甲醇氧化法、间接电化学氧化法、苯甲酸加氢 还原法和苠叉二氯水解法 ${ }^{[2]}$. 这些方法步骤过长, 成本 较高, 污染腐蚀较大. 甲苯在催化剂作用下以空气或者 氧气进行气相氧化制备苯甲醛是一条最为绿色环保的 路线, 但是有效催化剂的缺乏制约其发展和应用 ${ }^{[3]}$.

近年来, 以苯乙烯为原料催化氧化制备苯甲醛的方 法, 因其过程相对简单, 污染较小而广受人们关注 ${ }^{[4,5]}$. 其关键在于开发具有高效率、高选择性的催化剂. 目前

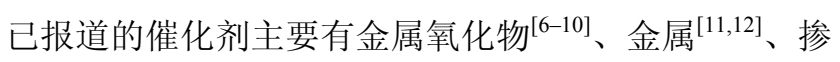
杂金属的分子篮 ${ }^{[13,14]}$ 、固体酸 ${ }^{[15,16]}$ 和金属席夫碱配合 物 ${ }^{[17,18]}$. 其中, 金属席夫碱配合物是一种活性较高的均 相催化剂, 但因难以从产物中分离回收循环使用而限制 了其工业应用. 将金属席夫碱配合物固载于分子

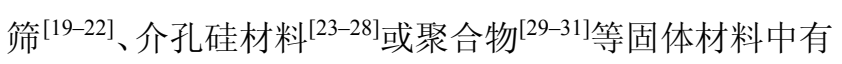
望克服这一问题. Islam 等 ${ }^{[29]}$ 对聚苯乙烯进行氨基改性 后, 制备了固定有 $\mathrm{Cu}$ 席夫碱的 $\mathrm{PS}-\mathrm{NH}_{2}-\mathrm{u}-\mathrm{Sal}$ 催化剂, 以 TBHP为氧化剂, 但是苯乙烯的转化率仅为 $53 \%$, 苯甲醛 选择性为 $52 \%$, 同时副产大量的环氧苯乙烷. Yang 等 ${ }^{[24]}$ 采用嫁接法以3-氨丙基三乙氧基硅烷(APTES) 改性 $\mathrm{SBA}-15$ 后, 在其上固定了一系列 $\mathrm{Cu}$ 和 $\mathrm{V}$ 的席夫碱络合 物, 并研究了其对苯乙烯氧化的催化活性. 结果表明, 在 以 $\mathrm{H}_{2} \mathrm{O}_{2}$ 为氧化剂时, VO-Salen-SBA催化剂对苯乙烯氧 化制苯甲醛有较好的选择性, 苯乙烯转化率可达 $84.1 \%$, 苯甲醛选择性为 $83.3 \%$, 但是反应需要在有机溶剂中进 行. 上述研究均采用将含氨基的硅烷偶联剂与材料表面 的羟基反应进行嫁接. 这种方法制得的载体虽然能保持 规整的孔道结构, 但其表面氨基的分布受硅烷偶联剂的 浓度和反应条件影响较大 ${ }^{[32-35]}$, 可能是导致催化剂活性
不高以及回收使用后活性显著下降的原因.

本文采用原硅酸四乙酯(TEOS)与APTES共水解的 方法制备氨基功能化的介孔分子篮 SBA-15 $\left(\mathrm{NH}_{2}\right.$-SBA-15), 然后通过缩合反应和配位反应制得 $\mathrm{Cu}(\mathrm{II})$ 席夫碱配合物多相催化剂Cu-SBA-15, 并研究了该 催化剂在无有机溶剂条件下催化氧化苯乙烯反应制备 苯甲醛的反应.

\section{2. 实验部分}

\section{1. 催化剂的制备}

\subsection{1. $\mathrm{NH}_{2}-\mathrm{SBA}-15$ 的制备}

$\mathrm{NH}_{2}-\mathrm{SBA}-15$ 的制备方法与文献[36]类似, 将 $4.0 \mathrm{~g}$ $\mathrm{P} 123$ (Sigma-Aldrich) 于 $40{ }^{\circ} \mathrm{C}$ 与 $125.0 \mathrm{~g}$ 稀盐酸 $(2 \mathrm{~mol} / \mathrm{L})$ 在 $500 \mathrm{~mL}$ 的三口烧瓶中剧烈搅拌 $4 \mathrm{~h}$ 后, 逐滴加入 $7.9 \mathrm{~mL}$ TEOS. 滴加完毕后, TEOS于 $40{ }^{\circ} \mathrm{C}$ 下预水解 $1 \mathrm{~h}$, 然后移 取 $0.92 \mathrm{~mL}$ 硅烷偶联剂 $\mathrm{KH} 550$ 迅速加入到烧瓶中. TEOS和KH550 (上海耀华化工厂) 共水解 $20 \mathrm{~h}$ 后, 将得 到的乳白色液体转移至聚丙烯的塑料小瓶中, 并于 $90{ }^{\circ} \mathrm{C}$ 下老化 $24 \mathrm{~h}$. 对所得的混合物抽滤, 并将滤饼于 $50{ }^{\circ} \mathrm{C}$ 烘箱中干燥过夜. 乙醇萃取回流 $24 \mathrm{~h}$ 除去 $\mathrm{NH}_{2}$-SBA-15 中残留的模板剂P123 (每克固体约需 $200 \mathrm{~mL}$ 乙醇与 $10 \mathrm{~mL}$ 浓盐酸)后, 用去离子水和乙醇洗涤 数次, 放入 $50{ }^{\circ} \mathrm{C}$ 烘箱中干燥过夜. 元素分析结果显示, $\mathrm{NH}_{2}$-SBA-15中各元素含量为(\%): C 8.00, H 3.27, N 1.53. 经计算得其表面氨基的含量为 $1.09 \mathrm{mmol} / \mathrm{g}$.

\subsubsection{Cu-SBA-15的制备}

将 $2.35 \mathrm{~g}$ 干燥的 $\mathrm{NH}_{2}-\mathrm{SBA}-15$ 悬浮于 $80 \mathrm{~mL}$ 的无水甲 醇中, 逐滴加入 $20 \mathrm{~mL}$ 的 $0.2 \mathrm{~mol} / \mathrm{L}$ 的水杨醛甲醇溶液 $(0.488 \mathrm{~g}$ 水杨醛), 水杨醛与氨基缩合, 反应液变为黄色. 在 $30{ }^{\circ} \mathrm{C}$ 反应 $6 \mathrm{~h}$ 后, 将水浴温度升至 $50^{\circ} \mathrm{C}$, 随后逐滴加 $入 0.1 \mathrm{~mol} / \mathrm{L}$ 的 $\mathrm{Cu}\left(\mathrm{NO}_{3}\right)_{2}$ 甲醇溶液 $10 \mathrm{~mL}$, 此时悬浮液中 由于 $\mathrm{Cu}$ 的配位而渐渐变为浅绿色. 反应 $12 \mathrm{~h}$ 后将固体过 
滤, 并用甲醇和去离子水先后洗涤数次至滤液无色. 将 制得的催化剂于 $80^{\circ} \mathrm{C}$ 烘箱中干燥过夜. 经原子发射光 谱法检测得 $\mathrm{Cu}$ 元素含量为 $0.101 \mathrm{mmol} / \mathrm{g}$.

\section{2. 催化剂表征}

采用Rigaku公司 X射线衍射仪(XRD)测定催化剂的 结构, $\mathrm{Cu}$ 靶 $K_{a}$ 射线, 管电压 $40 \mathrm{kV}$, 管电流 $30 \mathrm{~mA}$; 采用小 角度XRD分析Cu-SBA-15的结构, 扫描步长 $0.02^{\circ}$, 每步 扫描 $0.5 \%$ s. 采用美国Thermo公司Nicolet iS10型红外光 谱仪 (FT-IR) 表征样品, KBr 压片制样, 扫描范围 500-4000 $\mathrm{cm}^{-1}$. 用 HITACHIS4800 型场发射电镜 (FESEM)观察样品的表面形貌. 采用JEL-200CX型透射 电子显微镜(TEM)观察样品的孔道结构. 用PerkinElmer 公司Lambda950型紫外可见分光光度计(UV-Vis)表征催 化剂, 扫描范围为 200-800 nm. $\mathrm{N}_{2}$ 吸附-脱附等温线在 BELSORP II型体积吸附仪上测定, 吸附温度为 $-196^{\circ} \mathrm{C}$, $\mathrm{N}_{2}$ 吸附前, 样品在 $200{ }^{\circ} \mathrm{C}$ 真空条件下处理 $3 \mathrm{~h}$; 采用 BET 方程计算样品的比表面积 $A_{\mathrm{BET}}$, 根据相对压力为 0.99 时 $\mathrm{N}_{2}$ 的吸附量计算样品的总孔体积 $\left(V_{\text {total }}\right)$, 根据 $\mathrm{N}_{2}$ 等温线 的吸附分支用BJH方法计算样品的介孔孔径分布及峰值 孔径 $D_{\text {peak. }}$. 样品的热重分析 (TGA) 在 Netzsch 公司 STA409型同步热分析仪上进行, 以 $\mathrm{Al}_{2} \mathrm{O}_{3}$ 坩埚装载样品, 空气气氛, 升温速率 $10^{\circ} \mathrm{C} / \mathrm{min}$. CHN元素分析在Perkin Elmer 2400 上进行. $\mathrm{Cu}$ 含量通过等离子体发射光谱(ICP) 仪测定.

\section{3. 催化剂评价}

苯乙烯的氧化反应在 $100 \mathrm{~mL}$ 不锈钢高压反应釜(美 国Parr公司)中进行. 先在反应釜中加入一定量的催化 剂, 再称取一定质量的去离子水、 $30 \mathrm{wt} \%$ 的 $\mathrm{H}_{2} \mathrm{O}_{2}$ 和 $5.200 \mathrm{~g}$ 苯乙烯混合后倒入釜中将搅拌速度调节至 $800 \mathrm{r} / \mathrm{min}$, 当 温度升至 $100{ }^{\circ} \mathrm{C} 反$ 应开始计时. 反应结束后, 将产物离 心分离(离心机转速 $8000 \mathrm{r} / \mathrm{min}$, 时间 $2 \mathrm{~min}$ ), 并用乙酸乙 酯洗涤催化剂. 将所得的所有液体倒入梨型分液漏斗中 静置分层, 取上层有机相加入无水硫酸镁干燥后进行气 相色谱分析. 气相色谱分析在岛津GC-2014上进行, 色 谱柱为 DB-5 弹性毛细管 $\mathrm{MS}$ 柱 $(30 \mathrm{~m} \times 0.25 \mathrm{~mm} \times 0.25$ $\mu \mathrm{m})$, 进样口温度为 $260^{\circ} \mathrm{C}$, 检测室温度为 $260^{\circ} \mathrm{C}$, 柱 温为 $90{ }^{\circ} \mathrm{C}$ 保持 $8 \mathrm{~min}$, 以 $20^{\circ} \mathrm{C} / \mathrm{min}$ 升温至 $200^{\circ} \mathrm{C}$ 保持 10 $\min$. 反应后的催化剂用丙酮、乙醇和去离子水先后洗涤 数次, 放入 $100{ }^{\circ} \mathrm{C}$ 烘箱中干燥过夜以回收.

\section{3. 结果与讨论}

\section{1. 催化剂的表征}

图 1(a)为 $\mathrm{NH}_{2}-\mathrm{SBA}-15$ 和 Cu-SBA-15的XRD谱. 可以 看到主峰明显, 所制材料具有SBA-15的结构, 但是后 2 个 小衍射峰并不明显, 这是由于硅烷偶联剂的加入影响了 胶束的形成, 使得材料的孔隙规整度发生了变化. 图 (b) 为 SBA-15, $\mathrm{NH}_{2}-\mathrm{SBA}-15$, Schiff-base-SBA-15 和 CuSBA-15的FT-IR 谱. 位于 $467,799,1081$ 和 $1230 \mathrm{~cm}^{-1}$ 处 的吸收峰表明其中存在着 $\mathrm{O}-\mathrm{Si}-\mathrm{O}$ 键, 而在 $946 \mathrm{~cm}^{-1}$ 处 的吸收峰证明了 $\mathrm{Si}-\mathrm{OH}$ 的存在. 所有样品在 $1632 \mathrm{~cm}^{-1}$ 左右的较强的吸收峰均是由催化剂吸附的水分子产生, 而在2800-3700 $\mathrm{cm}^{-1}$ 左右出现的强吸收峰是由其自身 表面上的羟基以及其吸附的水分子的羟基产生的伸缩 振动引起. 在 3250 和 $1510 \mathrm{~cm}^{-1}$ 处的吸收峰分别由 $-\mathrm{NH}_{2}$ 的伸缩振动和弯曲振动产生, 而 $668 \mathrm{~cm}^{-1}$ 处的小峰则由 $\mathrm{N}-\mathrm{H}$ 的弯曲振动产生, 表明 $\mathrm{NH}_{2}-\mathrm{SBA}-15$ 中存在 $-\mathrm{NH}_{2}$ 基 团. 在 Schiff-base-SBA-15 和 Cu-SBA-15 样品中也在 $1510 \mathrm{~cm}^{-1}$ 附近出现吸收峰, 但是强度明显减弱, 表明催 化剂表面的 $-\mathrm{NH}_{2}$ 基团与水杨醛发生了缩合反应, 形成 席夫碱结构. 由于通常 $\mathrm{C}=\mathrm{N}$ 双键伸缩振动在 1640-1450 $\mathrm{cm}^{-1}$ 处产生较为微弱吸收, 与 $\mathrm{H}_{2} \mathrm{O}$ 分子的伸缩振动产生 的红外吸收处于同一区域而被其掩盖, 所以 $\mathrm{C}=\mathrm{N}$ 键特 征峰并不明显. 比较Schiff-base-SBA-15和 Cu-SBA-15 的FT-IR 谱, 发现后者在 $1387 \mathrm{~cm}^{-1}$ 处出现了一个新吸收 峰, 这可能是由于 $\mathrm{Cu}$ 和席夫碱配位引起了 $\mathrm{C}=\mathrm{N}$ 键吸收 的红移.

图2(a)为 $\mathrm{NH}_{2}$-SBA-15 的FESEM照片. 发现该样品 呈短棒状, 是SBA-15典型形貌. 图2(b) 为 $\mathrm{NH}_{2}-\mathrm{SBA}-15$ 的 粒径分布图, 其粒径大多在 600-700 nm, 平均粒径为 740 $\mathrm{nm}$. 图 2(c) 与 (d) 分别为 $\mathrm{NH}_{2}-\mathrm{SBA}-15$ 及 $\mathrm{Cu}-\mathrm{SBA}-15$ 的 TEM照片. 可以看出, 两者的孔道结构均为规整的六方 形孔道, 但是其中有少量发生了局部孔道坍塌. 这与 XRD谱中显示的小衍射峰不明显相一致.

图3 为 $\mathrm{NH}_{2}-\mathrm{SBA}-15$ 和 $\mathrm{Cu}-\mathrm{SBA}-15$ 的UV-Vis 谱. 可以 看出, 相比于 $\mathrm{NH}_{2}$-SBA-15, Cu-SBA-15于 $\lambda=390 \mathrm{~nm}$ 处有 一个吸收峰, 由配体向过渡金属的电荷转移产生 ${ }^{[24]}$, 证 明铜的席夫碱络合物成功负载于SBA-15表面.

图4为 $\mathrm{NH}_{2}-\mathrm{SBA}-15$ 和 $\mathrm{Cu}-\mathrm{SBA}-15$ 的 $\mathrm{N}_{2}$ 吸附曲线和孔 径分布图. 可以看出, $\mathrm{NH}_{2}-\mathrm{SBA}-15$ 的 $\mathrm{N}_{2}$ 吸附脱附等温线 均为 IV 型, 其滞后回环为 $\mathrm{H} 1$ 型, 而 Cu-SBA-15 中的等温 线虽仍为 IV 型, 但其滞后回环变为 $\mathrm{H} 2$ 型, 表明负载后有 部分孔道发生了堵塞. 另外, 两者孔径分布峰值虽均为 $5.41 \mathrm{~nm}$, 然而负载后的 Cu-SBA-15的强度降低, 孔径分 布发生了宽化. 两者的比表面积、孔体积和孔径见表1. 
相比于 $\mathrm{NH}_{2}-\mathrm{SBA}-15, \mathrm{Cu}-\mathrm{SBA}-15$ 的比表面积和孔体积略 有减小. 这可能主要是由于负载过程中, 铜席夫碱的引 入使得部分通道口变小或发生堵塞.

图 5 为 $\mathrm{NH}_{2}-\mathrm{SBA}-15$ 和 $\mathrm{Cu}-\mathrm{SBA}-15$ 的TGA结果. 可以 看到, 在温度低于 $100{ }^{\circ} \mathrm{C}$ 时出现的重量损失对应于催化 剂表面物理吸附的水, $200-350{ }^{\circ} \mathrm{C}$ 左右质量的减少为氨 基和席夫碱配合物的分解所致. 由于席夫碱络合物的质 量大于氨基的质量, 故在 $\mathrm{Cu}-\mathrm{SBA}-15$ 上的质量减少比 $\mathrm{NH}_{2}$-SBA- 15 快. 在 $350{ }^{\circ} \mathrm{C}$ 后催化剂质量继续减少, 归属 于三甲基硅烷基团的分解.

\section{2. 反应条件的优化}

\subsection{1. 反应时间的影响}

图6(a)为在反应温度为 $100{ }^{\circ} \mathrm{C}, \mathrm{H}_{2} \mathrm{O}_{2}$ 用量为 1.5 倍当 量且浓度为 $10 \mathrm{wt} \%$, 催化剂用量 $0.300 \mathrm{~g}$ 的条件下, 苯乙 烯的转化率与产物苯甲醛的选择性随时间的变化规律. 由图可见, 随着反应时间的延长, 苯乙烯的转化率提高, 苯甲醛的选择性缓慢下降, 至 $8 \mathrm{~h}$ 时, 转化率达到 $55.4 \%$, 选择性在 $80 \%$ 左右; 但延长至 $9 \mathrm{~h}$ 时, 苯乙烯发生聚合, 苯乙烯的转化率提高, 但产物选择性大大降低, 这可能 是由于时间过长时, 釜中的 $\mathrm{H} 2 \mathrm{O} 2$ 已完全消耗, 苯乙烯无 法再被氧化而在高温下发生聚合所致.

\subsection{2. 反应温度的影响}

在 $\mathrm{H}_{2} \mathrm{O}_{2}$ 用量为 1.5 倍当量, 浓度为 $10 \mathrm{wt} \%$, 催化剂用 量 $0.300 \mathrm{~g}$, 反应时间为 $8 \mathrm{~h}$ 条件下, 对反应温度的影响进 行了考察, 结果见图6(b). 降低反应温度使苯乙烯转化 率迅速下降; 如 $80{ }^{\circ} \mathrm{C}$ 时苯乙烯转化率只有 $6.8 \%$. 但是 反应的选择性在温度较低时较高, 这是由于该条件下苯 甲醛氧化成苯甲酸的速度也相对较慢. 当于 $100{ }^{\circ} \mathrm{C}$ 反应 $8 \mathrm{~h}$, 苯乙烯的转化率为 $55.4 \%$, 苯甲醛的选择性为 $79.3 \%$.

\subsection{3. $\mathrm{H}_{2} \mathrm{O}_{2}$ 用量的影响}

固定反应时间为 $8 \mathrm{~h}$, 反应温度为 $100^{\circ} \mathrm{C}$, 水量为 $17.167 \mathrm{~g}$ 以及催化剂用量为 $0.300 \mathrm{~g}$, 对 $\mathrm{H}_{2} \mathrm{O}_{2}$ 的用量进行 了考察, 结果见图6(c). 可以看出, 随着 $\mathrm{H}_{2} \mathrm{O}_{2}$ 用量的增加, 苯乙烯的转化率逐渐增加, 当 $\mathrm{H}_{2} \mathrm{O}_{2}$ 用量为 2 倍当量时转 化率为 $70.6 \%$, 苯甲醛选择性为 $79.6 \%$; 至 2.5 倍当量时, 虽然转化率提高至 $84.5 \%$, 但选择性迅速下降为 $65.4 \%$. 这是由于 $\mathrm{H}_{2} \mathrm{O}_{2}$ 用量的增加虽加快了反应, 但是也使得苯 甲醛发生进一步氧化变为苯甲酸, 故选择性下降. 所以, 当 $\mathrm{H}_{2} \mathrm{O}_{2}$ 用量为 2 倍当量时相对较好.

\subsection{4. $\mathrm{H}_{2} \mathrm{O}$ 用量的影响}

由于反应中不添加有机溶剂, 苯乙烯直接与 $\mathrm{H}_{2} \mathrm{O}_{2}$ 进 行两相反应, 故水量的多少间接影响着 $\mathrm{H}_{2} \mathrm{O}_{2}$ 的浓度. 在
反应时间为 $8 \mathrm{~h}$, 温度为 $100{ }^{\circ} \mathrm{C}, \mathrm{H}_{2} \mathrm{O}_{2}$ 用量为 2 倍当量, 催 化剂用量为 $0.300 \mathrm{~g}$ 条件下, 我们考察了反应中 $\mathrm{H}_{2} \mathrm{O}$ 量对 反应的影响, 结果如图6(d)所示. 可以看出, 当原料中不 额外添加 $\mathrm{H}_{2} \mathrm{O}$ 时, 反应的转化率最高; 随着 $\mathrm{H}_{2} \mathrm{O}$ 量的增 加, 反应的转化率明显下降. 因此 $\mathrm{H}_{2} \mathrm{O}$ 的引入不利于反 应进行, 反应中无需再加入额外的 $\mathrm{H}_{2} \mathrm{O}$.

\subsection{5. 催化剂用量的影响}

图6(e)考察了在反应时间为 $8 \mathrm{~h}$, 温度为 $100{ }^{\circ} \mathrm{C}, \mathrm{H}_{2} \mathrm{O}_{2}$ 用量为 2 倍当量且不额外添加水的条件下催化剂用量的 影响. 当催化剂用量为 $0.200 \mathrm{~g}$ 时, 苯乙烯的转化率可达 到 $84.4 \%$, 苯甲醛选择性为 $83.9 \%$, 继续提高催化剂的用 量对反应的影响不大. 但是降低催化剂的用量至 0.150 和 $0.100 \mathrm{~g}$ 时, 产物中出现了少量高粘度物质, 可能为低 聚合度的聚苯乙烯. 所以较多的催化剂有利于促进氧化 反应的进行, 阻止苯乙烯的聚合.

综上, 以制得的 $\mathrm{Cu}-\mathrm{SBA}-15$ 为催化剂, $\mathrm{H}_{2} \mathrm{O}_{2}$ 为氧化 剂得到苯乙烯的转化率最高为 $84.4 \%$, 苯甲醛选择性为 $83.9 \%$, 副产物仅为苯甲酸, 无环氧苯乙烷的生成. 最优 反应条件为反应温度 $100{ }^{\circ} \mathrm{C}$, 反应时间 $8 \mathrm{~h}, \mathrm{H}_{2} \mathrm{O}_{2}$ 与苯乙 烯的比例为 $2: 1, \mathrm{H}_{2} \mathrm{O}_{2}$ 浓度为 $30 \mathrm{wt} \%$ 且不额外加水稀释, 催化剂用量为 $0.200 \mathrm{~g}$, 此时催化剂的 TOF为 $261.1 \mathrm{~h}^{-1}$. 在 最佳工艺条件下, 催化剂的 TOF高于文献中以直接嫁接 法合成的金属席夫碱催化剂, 且取得了与使用有机溶剂 条件下相近的转化率与选择性(见表2). 值得指出的是, 在该条件下加入乙腈作为共溶剂, 苯乙烯的转化率虽然 提高至 $96.7 \%$, TOF达 $299.2 \mathrm{~h}^{-1}$, 但是苯甲醛选择性, 仅为 $58.3 \%$, 且副产物除了苯甲酸外 $(16.7 \%)$, 还有苯乙醛 (15.8\%)和苯基乙二醇 $(9.2 \%)$.

\section{3. 催化剂的循环使用}

催化剂的循环利用实验(表3)表明, 在使用 3 次之 后活性无明显变化. 反应主要产物均为苯甲醛, 同时 生成少量苯甲酸, 未检测到有环氧苯乙烷生成. 利用 回收的催化剂时, 苯甲醛的选择性略微降低, 可能是 催化剂回收时未完全洗涤干净, 有少量残余的有机物 滞留于催化剂表面导致苯甲醛未及时脱附而过度氧 化. 总体上催化剂活性未发生明显变化, 催化剂可重 复循环使用.

\section{4. 苯乙烯的氧化反应机理}

在 $\mathrm{Cu}$ 席夫碱配合物催化下, 苯乙烯的氧化反应可能 通过两种反应路径生成苯甲醛 ${ }^{[27]}$, 如图式1所示. 第一 种为自由基氧化机理, $\mathrm{H}_{2} \mathrm{O}_{2}$ 分子在催化剂表面吸附, 在 固定于 SBA-15表面的 $\mathrm{Cu}$ 席夫碱配合物作为催化剂的活 
性中心作用下分解为羟基自由基, 后者加成到扩散进入 孔道的苯乙烯分子的 $\mathrm{C}=\mathrm{C}$ 双键上加成形成苄基羟亚甲 基自由基, 该自由基继续和羟基自由基反应生成1-苯乙 烷-1,2-二醇, 然后通过氧化裂解生成苯甲醛和甲醛, 苯 甲醛易被过度氧化生成苯甲酸. 另一条路线为, 苯乙烯 与活化的 $\mathrm{H}_{2} \mathrm{O}_{2}$ 分子直接发生氧化反应生成氧化苯乙烯, 后者继续被氧化生成羟基-过氧苯乙烯, 因不稳定而易 分解为苯甲醛和甲醛. 在反应进程中, 并未检测到环氧 苯乙烷的生成, 故当使用该Cu-SBA-15为催化剂时, 苯乙 烯的氧化可能遵循的是第一种反应机理. 因此若要苯乙 烯完全反应变成苯甲醛, 理论需消耗 2 倍当量的 $\mathrm{H}_{2} \mathrm{O}_{2}$. 所以, 当 $\mathrm{H}_{2} \mathrm{O}_{2}$ 用量较少时, 反应的转化率不高; 而当
$\mathrm{H}_{2} \mathrm{O}_{2}$ 用量远远超过 2 倍当量时, 苯甲醛越容易过度氧化 生成苯甲酸, 所以反应的选择性迅速下降.

\section{4. 结论}

以一步共水解法制得的 $\mathrm{NH}_{2}-\mathrm{SBA}-15$ 为载体, 在其 上嫁接 $\mathrm{Cu}$ 的席夫碱络合物, 用于无溶剂条件下催化苯乙 烯氧化制苯甲醛的反应中, 苯乙烯的转化率最高为 $84.4 \%$, 苯甲醛选择性为 $83.9 \%$, 催化剂的 TOF 达 261.1 $\mathrm{h}^{-1}$, 且催化剂重复使用 3 次活性不下降. 该催化剂活性 高于以液相嫁接法合成的. 这是由于, 一步法制得的载 体表面氨基分布更均匀,使得固定在催化剂表面的金属 络合物活性中心分布较好所致. 